\title{
Article
}

\section{The Effect of NUDT15, TPMT, APEX1, and ITPA Genetic Variations on Mercaptopurine Treatment of Pediatric Acute Lymphoblastic Leukemia}

\author{
Jae Min Lee ${ }^{1,+}$, , Ye Jee Shim ${ }^{2, \dagger}$, Do-Hoon Kim ${ }^{3}$, Nani Jung ${ }^{2}$ and Jung-Sook Ha ${ }^{3, *}$ \\ 1 Department of Pediatrics, Yeungnam University College of Medicine, Daegu 42415, Korea; \\ mopic@hanmail.net \\ 2 Department of Pediatrics, Keimyung University School of Medicine, Daegu 42601, Korea; \\ yejeeshim@dsmc.or.kr (Y.J.S.); lemon378@hanmail.net (N.J.) \\ 3 Department of Laboratory Medicine, Keimyung University School of Medicine, Daegu 42601, Korea; \\ kdh@dsmc.or.kr \\ * Correspondence: ksksmom@dsmc.or.kr; Tel.: +82-53-258-7938 \\ + These authors contributed equally to this work.
}

check for updates

Citation: Lee, J.M.; Shim, Y.J.; Kim, D.-H.; Jung, N.; Ha, J.-S. The Effect of NUDT15, TPMT, APEX1, and ITPA

Genetic Variations on

Mercaptopurine Treatment of Pediatric Acute Lymphoblastic Leukemia. Children 2021, 8, 224. https://doi.org/10.3390/ children 8030224

Academic Editor: Pantelis Perdikaris

Received: 16 January 2021

Accepted: 8 March 2021

Published: 15 March 2021

Publisher's Note: MDPI stays neutral with regard to jurisdictional claims in published maps and institutional affiliations.

Copyright: (c) 2021 by the authors. Licensee MDPI, Basel, Switzerland This article is an open access article distributed under the terms and conditions of the Creative Commons Attribution (CC BY) license (https:// creativecommons.org/licenses/by/ $4.0 /)$.

\begin{abstract}
Mercaptopurine (MP) is a commonly used maintenance regimen for childhood acute lymphoblastic leukemia (ALL). However, 6-MP has a narrow therapeutic index, which causes dose-limiting toxicities in hematopoietic tissues. Recent studies reported several candidate pharmacogenetic markers such as TPMT, NUDT15, ITPA, and APEX1, which predict the possibility of 6-MP related toxicities. The aim of this study is to evaluate the effect of major variants of these genes on 6-MP intolerances and toxicities in pediatric acute lymphoblastic leukemia (ALL) patients. A total of 83 pediatric ALL patients were included (56 males and 27 females). The NUDT15 c.415C > T (rs116855232), NUDT15 c.55_56insGAGTCG (rs746071566), ITPA c.94C>A (rs1127354), ITPA c.IVS2+21A >C (rs7270101), APEX c.190A >G (rs2307486), and TPMT variants were analyzed by sanger sequencing. Correlations between indexes of 6-MP-related toxicities or 6-MP intolerance (absolute neutrophil count [ANC] at several time point, days of ANC $<1 \times 10^{3} / \mathrm{mm}^{3}$, days of ANC $<0.5 \times 10^{3} / \mathrm{mm}^{3}$, frequency of febrile neutropenia, maximum AST and ALT, 6-MP dose and 6-MP dose intensity during maintenance therapy) and genetic variations were analyzed. The NUDT15 c. $415 \mathrm{C}>\mathrm{T}$ allele carrier showed significantly low 6-MP doses at the final maintenance therapy period than the wild type carrier ( $p=0.007)$. The 6-MP dose intensities at the sixth and final maintenance period were also significantly low in NUDT15 c.415C > T carriers ( $p=0.003$ and 0.008 , respectively). However, indexes for neutropenia, days of febrile neutropenia, maximum AST, and ALT levels were not associated with the presence of $c .415 \mathrm{C}>\mathrm{T}$ as well as other analyzed variants. When analyzing the effect of the coexistence of NUDT15 c.415C > T and ITPA c.94C >A, no significant differences were found between the NUDT15 c.415C > T carrier and carrier with both variations. The NUDT15 c. $415 \mathrm{C}>\mathrm{T}$ was the most useful marker to predict 6-MP intolerance among analyzed variants in our study population. Although we could not find association of those variants with 6-MP induced toxicities and the synergistic effects of those variants, a well-planed larger scale study would be helpful in clarifying new candidates and their clinical effects.
\end{abstract}

Keywords: 6-mercaptopurine; acute lymphoblastic leukemia; TPMT; NUDT15; ITPA; APEX

\section{Introduction}

Acute lymphoblastic leukemia (ALL) is the most common pediatric malignancy with overall survival rate of $80-90 \%$. One of contributors for this high survival rate is the maintenance therapy with 6-mercaptopurine (6-MP) [1].

Mercaptopurine, one of thiopurine drugs, is commonly used as a maintenance regimen for childhood ALL and has played an important role in long-term remission. However, $6-$ $\mathrm{MP}$ has a narrow therapeutic index. It then causes dose-limiting toxicities in hematopoietic 
tissues, resulting in neutropenia or febrile neutropenia. Because these toxicities negatively affect ALL treatment outcomes, there have been attempts to find the risk factors causing these toxicities especially in the pharmacogenetics area [2,3].

Mercaptopurine is converted to the main therapeutic metabolites 6-thioguanine nucleotides (TGNs), comprising thioguanosine- $5^{\prime}$-triphosphate (TGTP), thioguanosine- $5^{\prime}$ diphosphate (TGDP), and thioguanosine- $5^{\prime}$-monophosphate (TGMP) by multi-enzymatic steps [4]. TGNs have wide spectrum immunosuppressive roles by incorporation into RNA or DNA and inhibit DNA synthesis [5,6]. Thiopurine S-methyltransferase (TPMT) is the principal enzyme in the regulation of thiopurine metabolism by metabolizing TGNs to inactive, nontoxic compounds. Patients with a nonfunctional variant allele of TPMT have lower TPMT enzyme activity, and consequently 6-TGN excessively accumulates in hematopoietic tissues and frequently causes hematopoietic toxicity [7-9]. These findings lead to the concept of individualized 6-MP dosing according to TPMT genotype. However, TPMT alone cannot account for the individual-specific differences in 6-MP sensitivity [3], and the frequency of the variant TPMT alleles differs between ethnic groups [10]. Although approximately $10 \%$ of the Caucasian population carries a nonfunctional sequence variant, its frequency is exceptionally low in Asian populations, which brought limits to the application of the TPMT genotype to regulating dose of 6-MP in Asian ALL patients [11].

Recently, several other genes related to thiopurine toxicity have been reported. Nucleoside diphosphate-linked moiety X-type motif 15 (NUDT15) is a nucleotide diphosphatase that can convert TGTP to TGMP and is thus responsible for the inactivation of thiopurine metabolites [12]. A nonsynonymous rs116855232 NUDT15 variant (c.415C > T, p.Arg139Cys) has been reported as a strong risk factor for thiopurine-induced leukopenia and 6-MP intolerance in patients with inflammatory bowel disease and pediatric ALL in several reports [12-17]. As the frequency of this SNP is $\sim 6-10 \%$ of the East Asian population, NUDT15 has been suggested as a useful alternative marker for TPMT variants in East Asians [18]. Other SNPs in NUDT15 such as p.Arg139His, p.Val18Ile, p.Val18_Val19insGlyVal, p.Arg34Thr, p.Lys35-Glu, p.Gly17_Val18del, p.Met1Thr, and p.Gly47Arg have also been uncovered and are undergoing evaluation [12-17].

Inosine triphosphate pyrophosphatase (ITPA) is another enzyme involved in 6-MP metabolism. ITPA catalyzes the hydrolysis of inosine triphosphate (ITP) to inosine monophosphate (IMP), protecting cells from the accumulation of harmful nucleotides such as ITP and deoxyinosine triphosphate [19]. The most well established deleterious ITPA variants associated with 6-MP-related toxicity are rs1127354 (c.94C>A) and rs7270101 (IVS2+21A >C) [20]. ITPA enzyme deficiency arising from genetic variants affects $5-7 \%$ of Caucasians and Africans, and up to $15 \%$ of Asians [21]. Despite the high frequency of these variation, their clinical relevance in the predictive role for 6-MP toxicities is still controversial.

Apurinic/apyrimidinic endonuclease 1 (APEX1) is another gene candidate reported recently. The missense variation rs2307486 (c.190A $>$ G) in APEX1 is strongly related to early onset MP-related neutropenia in pediatric ALL patients [22]. Although human APEX1 is the major enzyme in the DNA base excision repair pathway, and APEX1-deficient cells have been shown to exhibit sensitivity to antimetabolites in an in vivo study [23], its clinical relevance in 6-MP treatment has yet not been evaluated much.

The aim of this study is to identify the frequencies of major polymorphisms of candidate genes, TPMT, NUDT15, ITPA, and APEX1, and evaluate whether these variations and combination of them could predict 6-MP intolerance and toxicity during maintenance therapy in pediatric ALL patients.

\section{Materials and Methods}

\subsection{Patients and Data Collection}

This study was conducted according to the tenets of the Declaration of Helsinki with the approval of the institutional ethics committee (IRB No. 2019-11-074 Keimyung University Dongsan Hoispital, 2019-12-0072 Yeungnam University Hospi-tal). A total of 83 pediatric ALL patients were analyzed, including 56 males and 27 females. The 
median age at diagnosis was 8.3 years (range: 1.0-16.2 years). There were 52 patients who were allocated to the standard-risk group, 25 to the high-risk group, and six were in the very high-risk group, in accordance with National Cancer Institute (NCI) risk group classification [24,25]. The median follow-up duration was 9.1 years (range: 0.9-16.6 years) (Table 1).

Table 1. Characteristics and genotype frequencies of pediatric acute lymphoblastic leukemia patients enrolled in this study.

\begin{tabular}{|c|c|}
\hline Characteristics & \\
\hline Total number of patients, $n(\%)$ & 83 \\
\hline \multicolumn{2}{|l|}{ Sex, $n(\%)$} \\
\hline Female & $27(32.5)$ \\
\hline Male & $56(67.5)$ \\
\hline \multicolumn{2}{|l|}{ Risk group, $n(\%)$} \\
\hline Standard risk & $52(62.7)$ \\
\hline High risk & $25(30.1)$ \\
\hline Very high risk & $6(7.2)$ \\
\hline Age at diagnosis, median (range) & $8.3(1.0-16.2)$ \\
\hline \multicolumn{2}{|l|}{ Leukemia type, $n(\%)$} \\
\hline B-ALL & $68(81.9)$ \\
\hline T-ALL & $8(9.6)$ \\
\hline Mixed-type & $4(4.8)$ \\
\hline Unclassified & $3(3.6)$ \\
\hline \multicolumn{2}{|l|}{ Cytogenetic abnormality, $n(\%)$} \\
\hline Normal & $28(33.7)$ \\
\hline Hyperdiploidy & $13(15.7)$ \\
\hline $\mathrm{t}(12 ; 21)(\mathrm{p} 13 ; \mathrm{q} 22) ; E T V 6-R U N X 1$ & $12(14.5)$ \\
\hline $\mathrm{t}(4 ; 11)(\mathrm{q} 21 ; \mathrm{q} 23) ; M L L-A F F 1$ & $3(3.6)$ \\
\hline $\mathrm{t}(1 ; 19)(\mathrm{q} 23 ; \mathrm{p} 13.3) ;$ TCF3-PBX1 & $3(3.6)$ \\
\hline $\mathrm{t}(9 ; 22)(\mathrm{q} 34 ; \mathrm{q} 11.2) ; B C R-A B L 1$ & $1(1.2)$ \\
\hline Hypodiploidy & $1(1.2)$ \\
\hline Other/unknown & $22(26.5)$ \\
\hline \multicolumn{2}{|l|}{ Neutropenia (mean $\pm \mathrm{SD}$ ) } \\
\hline ANC at 14 th day $\left(/ \mathrm{mm}^{3}\right)$ & $708.8 \pm 824.1$ \\
\hline ANC at 28 th day $\left(/ \mathrm{mm}^{3}\right)$ & $188.6 \pm 383.4$ \\
\hline Days of ANC $<1 \times 10^{3} / \mathrm{mm}^{3}(n=76)$ & $268.3 \pm 224.8$ \\
\hline Days of ANC $<0.5 \times 10^{3} / \mathrm{mm}^{3}(n=70)$ & $136.8 \pm 132.0$ \\
\hline Days of febrile neutropenia $(n=61)$ & $6.1 \pm 5.3$ \\
\hline \multicolumn{2}{|l|}{ 6-MP dose $\left(\mathrm{mg} / \mathrm{m}^{2}\right.$, mean $\left.\pm \mathrm{SD}\right)$} \\
\hline First maintenance & 75 \\
\hline Second maintenance & $51.6 \pm 19.1$ \\
\hline Sixth maintenance & $48.5 \pm 16.5$ \\
\hline Final maintenance & $45.3 \pm 15.3$ \\
\hline \multicolumn{2}{|l|}{ 6-MP dose intensity * } \\
\hline Second maintenance & $70.0 \pm 24.8$ \\
\hline Sixth maintenance & $66.3 \pm 22.5$ \\
\hline Final maintenance & $61.7 \pm 21.0$ \\
\hline Maximum AST, (IU, mean \pm SD) & $303.9 \pm 220.7$ \\
\hline Maximum ALT, (IU, mean \pm SD) & $636.3 \pm 458.6$ \\
\hline \multicolumn{2}{|l|}{ Genotype, $n(\%)$} \\
\hline \multicolumn{2}{|l|}{ NUDT15 55_56insGAGTCG (rs746071566) } \\
\hline Wild & $74(89.2)$ \\
\hline 55_56insGAGTCG & $9(10.8)$ \\
\hline \multicolumn{2}{|l|}{ NUDT15 c.415C>T (rs116855232) } \\
\hline $\mathrm{CC}$ & $67(80.7)$ \\
\hline CA & 16 (19.3) \\
\hline \multicolumn{2}{|l|}{ ITPA c. $94 \mathrm{C}>\mathrm{A}(\mathrm{rs} 1127354)$} \\
\hline $\mathrm{CC}$ & $62(74.7)$ \\
\hline $\mathrm{CA}$ & $21(25.3)$ \\
\hline \multicolumn{2}{|l|}{ ITPA c.IVS2+21A>C (rs7270101) } \\
\hline AA & $82(98.8)$ \\
\hline AC & $1(1.2)$ \\
\hline
\end{tabular}


Table 1. Cont.

\begin{tabular}{|c|c|}
\hline Characteristics & \\
\hline \multicolumn{2}{|l|}{ APEX1 c.190A>G (rs2307486) } \\
\hline AA & $74(89.2)$ \\
\hline AG & $9(10.8)$ \\
\hline \multicolumn{2}{|l|}{ TPMT } \\
\hline$* 1 /{ }^{*} 1$ & $82(98.8)$ \\
\hline$* 1 / * 3$ & $1(1.2)$ \\
\hline NUDT15 с. $415 \mathrm{C}>\mathrm{T}+$ ITPA c. $94 \mathrm{C}>\mathrm{A}$ & $5(6.0)$ \\
\hline NUDT15 c. $415 \mathrm{C}>\mathrm{T}+$ APEX1 c. $190 \mathrm{~A}>\mathrm{G}$ & $1(1.2)$ \\
\hline TPMT ${ }^{*} 1 / * 3+I T P A$ c. $94 \mathrm{C}>\mathrm{A}$ & $1(1.2)$ \\
\hline ITPA с. $94 \mathrm{C}>\mathrm{A}+$ APEX1 с. $190 \mathrm{~A}>\mathrm{G}$ & $2(2.4)$ \\
\hline
\end{tabular}

ANC, absolute neutrophil count; 6-MP, 6-mercaptopurine; NUDT15, nucleoside diphosphate-linked moiety X-type motif 15; ITPA, inosine triphosphate pyrophosphatase; APEX1, apurinic/apyrimidinic endonuclease 1; TPMT, thiopurine S-methyltransferase.

Maintenance chemotherapy consisted of oral prednisolone $\left(40 \mathrm{mg} / \mathrm{m}^{2}\right)$ for five days and intravenous vincristine $\left(1.5 \mathrm{mg} / \mathrm{m}^{2}\right)$ every four weeks, daily oral 6-MP $\left(75 \mathrm{mg} / \mathrm{m}^{2}\right)$, weekly oral methotrexate (MTX) $\left(15 \mathrm{mg} / \mathrm{m}^{2}\right)$, and intrathecal chemotherapy (MTX alone or triple regimen [MTX, cytarabine, and hydrocortisone]) every 12 weeks. The doses of 6-MP and MTX were adjusted according to the complete blood count (CBC) and liver function tests (LFT) by a blood test every two weeks. During the maintenance chemotherapy, the target WBC values were 1.5-3.5 $\times 10^{3} / \mathrm{mm}^{3}$ with ANC $<1.5-2.0 \times 10^{3} / \mathrm{mm}^{3}[26,27]$. The medications were interrupted if the patients developed a grade three or greater hepatic toxicity, based on the Common Terminology Criteria for Adverse Events version 5.0 (CTCAE 5.0); if aspartate aminotransferase (AST) or alanine aminotransferase (ALT) $>5.0-20.0 \times$ upper limits of normal (ULN), or for a blood bilirubin > 3.0-10.0 $\times$ ULN. The medications were also stopped in cases of grade three or greater hematologic toxicities (ANC $<1.0-0.5$ $\times 10^{3} / \mathrm{mm}^{3}$ ) with a febrile infectious event occurring during maintenance chemotherapy.

Neutropenia is defined as a neutrophil count of $0.5 \times 10^{3} / \mathrm{mm}^{3}$ or less. For early neutropenia, ANC at 14th day and 28th day were analyzed. Febrile neutropenia is defined as two or more temperature spikes of $38.0^{\circ} \mathrm{C}$ or greater at least 1 hour apart, or as a single spike of $38.3{ }^{\circ} \mathrm{C}$ or greater, along with a neutrophil count of $0.5 \times 10^{3} / \mathrm{mm}^{3}$ or less at the time of the fever or a decrease to $0.5 \times 10^{3} / \mathrm{mm}^{3}$ or less within $48 \mathrm{~h}$ of fever onset. Numbers of neutropenia and febrile neutropenia episodes during maintenance therapy were retrospectively collected using patient medical records.

Data of a 6-MP dose and a 6-MP dose intensity (\%) was collected on the 13th (2nd maintenance period), and the 61st (6th maintenance period) week during maintenance chemotherapy, as well as at the final maintenance period. The 6-MP dose intensity (\%) was calculated as the ratio of the actual prescribed 6-MP dose by physician and the protocol dose. Hepatotoxicity was defined as an ALT or AST level $>200 \mathrm{U} / \mathrm{L}$ at any time point during maintenance therapy.

\subsection{Genotyping}

Genotyping for the following polymorphisms from five genes was performed: NUDT1 5 c.415C $>$ T (rs116855232), NUDT15 c.55_56insGAGTCG (rs746071566), ITPA c.94C >A (rs1127 354), ITPA c.IVS2+21A>C (rs7270101), APEX1 c.190A>G (rs2307486), TPMT*2 c.238G $>\mathrm{C}(\mathrm{rs} 1800462), T P M T * 3 B$ c.460G $>A$ (rs1800460), TPMT*3C c.719A $>\mathrm{G}(\mathrm{rs} 1142345)$, $T P M T * 4$ c.626-1G $>\mathrm{A}$ (rs1800584), and TPMT*3A being the combination of the TPMT*3B and TPMT $3 \mathrm{C}$ genotypes.

Genomic DNA was isolated from $150 \mu \mathrm{L}$ peripheral blood using the QIAamp DNA blood Mini kit from Qiagen (Germantown, MD, USA) and stored at $-20^{\circ} \mathrm{C}$ until analysis. Amplification was performed using Smart Tag Premix (Solgent Co., Daejeon, Korea). Briefly, $200 \mathrm{ng}$ of DNA template and $1 \mu \mathrm{L}$ each of forward and reverse primers were added to the PCR premix ( $20 \mu \mathrm{L}$ final volume). Sanger sequencing was performed using the following primers: NUDT15 c.415C $>$ T, forward 5'-CAAGCAAATGCAAAGCATCA reverse 5'-GGCTGAAAGAGTGGGGGATA; NUDT15 c.55_56insGAGTCG, forward 5'- 
GCGCTCTCGCTTTGATTTC reverse 5'-GAACGCGCAAGAAAGGAC; ITPA c.94C>A and IVS2+21A $>C$, forward 5'-TAGGAGATGGGCAGCAGAGT reverse 5'-CCTGGAAGCT ACCTGGACAA; APEX1 c.190A>G, forward 5'-CAGTTGGAAACCACCAGCTT reverse 5CAGAAAACTACGGGCAGGAG; TPMT c.238G>C, forward 5'-TCCTGCATGTTCTTTGAA ACC reverse 5'-TCGGTGATTGGTTCTTCTGA; TPMT c.460G >A, forward 5'-GGGACGCTG CTCATCTTCT reverse $3^{\prime}$-TTCAAACTCATAGAAGTCTAAGCTGAT; TPMT c.719A>G and c.626-1G>A, forward 5'-GAATCCCTGATGTCATTCTTCA reverse 5'-CATTACATTTTCAG GCTTTAGCA.

Amplification parameters were an initial denaturation step of $95^{\circ} \mathrm{C}$ for $30 \mathrm{~s}$, annealing at $60{ }^{\circ} \mathrm{C}$ for $30 \mathrm{~s}$, and extension at $72{ }^{\circ} \mathrm{C}$ for $45 \mathrm{~s}$ for all reactions. The quality and sizes of PCR products were assessed by electrophoresis in a $1.5 \%$ agarose gel. Products were purified and bidirectionally sequenced using a BigDye Terminator v3.1 Cycle Sequencing kit (Applied Biosystems, Foster City, CA, USA) on an ABI 3500x1 DNA analyzer (Applied Biosystems, 850 Lincoln Centre Drive, Foster City, CA, USA). Mutations were identified using the Sequencher software (version 5.4.5).

\subsection{Statistical Analysis}

Data was entered and analyzed in SPSS v.26 (IBM Corporation, Armonk, NY, USA). Correlations between the index of 6-MP-related toxicities (absolute neutrophil count [ANC], days of ANC $<1 \times 10^{3} / \mathrm{mm}^{3}$, days of ANC $<0.5 \times 10^{3} / \mathrm{mm}^{3}$, frequency of febrile neutropenia, maximum AST and ALT), 6-MP intolerance (6-MP dose and 6-MP dose intensity at second, sixth and final maintenance therapy periods), and genetic variations were analyzed using Mann-Whitney U test. A p-value of less than 0.05 was considered statistically significant.

\section{Results}

\subsection{Patient Characteristics, Genotype Data, and Allele Frequencies}

Most of the enrolled children experienced episodes of neutropenia during the entire period of maintenance therapy. Seventy-six (91.6\%) children experienced $<1 \times 10^{3} / \mathrm{mm}^{3}$ neutropenia during at least one day (268.3 \pm 224.8 days), and $70(84.3 \%)$ children experienced $<0.5 \times 10^{3} / \mathrm{mm}^{3}$ neutropenia during $136.8 \pm 132.0$ days. Sixty-one $(73.5 \%)$ children experienced febrile neutropenia during $6.1 \pm 5.3$ days. An ANC at the 14th day and 28th day from initiation of maintenance therapy was $708.8 \pm 824.1 / \mathrm{mm}^{3}$, and $188.6 \pm 383.4 / \mathrm{mm}^{3}$, respectively. The 6-MP dose was started at $75 \mathrm{mg} / \mathrm{m}^{2}$ for all patients and an adjusted dose at the second, sixth, and final maintenance therapy cycles were $51.6 \pm 19.1 \mathrm{mg} / \mathrm{m}^{2}, 48.5 \pm 16.5 \mathrm{mg} / \mathrm{m}^{2}$, and $45.3 \pm 15.3 \mathrm{mg} / \mathrm{m}^{2}$, respectively. The 6-MP dose intensities were $70.0 \pm 24.8 \%, 66.3 \pm 22.5 \%$, and $61.7 \pm 21.0 \%$, respectively. The maximum AST, ALT levels during maintenance therapy were 303.9 $\pm 220.7 \mathrm{IU} / \mathrm{L}$ and $636.3 \pm 458.6 \mathrm{IU} / \mathrm{L}$, respectively (Table 1$)$. The differences of these indices according to age group ( $<10, \geq 10$ years), risk group (intermediate, high, and very high groups), and sex were not found (data not shown).

Genotype frequencies for NUDT15 c.415C>T, NUDT15 c.55_56insGAGTCG, ITPA c.94C >A, ITPA c.IVS2+21A >C, APEX1 c.190A >G, and TPMT are summarized in Table 1. Of the 83 children tested, $46(55.4 \%)$ carried at least one of the sequence variants of them: NUDT15 c.415C>T, 16 (19.3\%); NUDT15 c.55_56insGAGTCG, 9 (10.8\%); ITPA c.94C>A, $21(25.3 \%) ;$ ITPA c.IVS2+21A>C, 1 (1.2\%); APEX1 c.190A >G, 9 (10.8\%); TPMT variant 1*/3*, 1 (1.2\%). Eight of the NUDT15 c.55_56insGAGTCG carriers were accompanied by c.415C >T as diplotype $* 1 /{ }^{*}$, and only one patient carried the sole c.55_56insGAGTCG as diplotype ${ }^{*} 1 /{ }^{*} 6$ [18]. Nine patients carried more than 2 variants and combinations of them are listed in Table 1. Because of low allele frequency or co-occurrence with c.415C $>\mathrm{T}$, the variant of TPMT, ITPA IVS2+21A >C and NUDT15 c.55_56insGAGTCG were excluded in the analysis as an independent pharmacogenetic markers. 


\subsection{Associations between Genetic Polymorphisms and 6-Mercaptopurine Related Toxicities and Intolerances}

When the entire maintenance treatment period had been considered, there was no statistically significant associations between the investigated sequence variants and neutropenia (those experienced on days of $<5 \times 10^{3}$ and $<1 \times 10^{3} / \mathrm{mm}^{3}$ neutropenia, days of febrile neutropenia, ANC at 14th and 28th day) (Table 2). The NUDT15 c.415C $>$ T carriers were likely to have a lower ANC on the 28th day than the wild type, but this was not statistically significant (Table 2). When considering the 6-MP doses at second, sixth, and final maintenance therapy sessions, the NUDT15 c.415C $>$ T allele carrier showed significantly low 6-MP doses at final maintenance therapies than the wild type carrier $(p=0.007$ respectively) (Figure 1). The 6-MP dose intensities at the sixth and final maintenance period were also significantly low in NUDT15 c.415C > T carriers ( $p=0.003$ and 0.008 , respectively) (Figure 2). Maximum AST, and ALT levels were not associated with variants. Because of the low number of patients carrying more than two variants, their synergic effect could not be analyzed except for the NUDT15 c.415C > T and ITPA c.94C >A. When analyzing the effect of the coexistence of NUDT15 c.415C $>$ T and ITPA c.94C > A, no 6-MP toxicity differences were found between the NUDT15 c.415C > T carrier and carrier with both variations (Table S1).

Table 2. Relationships between genotypes of candidate genes and parameters for 6-MP-related toxicities and intolerance.

\begin{tabular}{|c|c|c|c|c|c|c|c|c|c|}
\hline \multirow[b]{2}{*}{ Charcteristics } & \multicolumn{3}{|c|}{ ITPA rs1127354 } & \multicolumn{3}{|c|}{$A P E X 1$ rs2307486 } & \multicolumn{3}{|c|}{ NUDT15 rs116855232 } \\
\hline & Genotype & $\begin{array}{l}\mathrm{CC}(n=62) \\
\mathrm{CA}(n=21)\end{array}$ & $p$ & Genotype & $\begin{array}{c}\text { AA }(n=74) \\
\text { AG }(n=9)\end{array}$ & $p$ & Genotype & $\begin{array}{l}\text { CC }(n=67) \\
\text { CT }(n=16)\end{array}$ & $p^{*}$ \\
\hline \multirow{2}{*}{ 14th day $\mathrm{ANC}\left(/ \mathrm{mm}^{3}\right)$} & $\mathrm{CC}$ & $\begin{array}{c}1588.2 \pm \\
1175.2\end{array}$ & \multirow[t]{2}{*}{0.539} & AA & $\begin{array}{c}1730.8 \pm \\
1577.8\end{array}$ & \multirow[t]{2}{*}{0.070} & $\mathrm{CC}$ & $\begin{array}{c}1688.1 \pm \\
1627.5\end{array}$ & \multirow[t]{2}{*}{0.884} \\
\hline & CA & $\begin{array}{c}1850.4 \pm \\
2269.3\end{array}$ & & AG & $\begin{array}{c}814.5 \pm \\
740.1\end{array}$ & & $\mathrm{CT}$ & $\begin{array}{c}1421.5 \pm \\
1087.5\end{array}$ & \\
\hline \multirow{2}{*}{ 28th day ANC $\left(/ \mathrm{mm}^{3}\right)$} & $\mathrm{CC}$ & $\begin{array}{c}1482.2 \pm \\
1112.5\end{array}$ & \multirow[t]{2}{*}{0.379} & AA & $\begin{array}{c}1425.9 \pm \\
1169.3\end{array}$ & \multirow[t]{2}{*}{0.677} & $\mathrm{CC}$ & $\begin{array}{c}1561.5 \pm \\
1223.8\end{array}$ & \multirow[t]{2}{*}{0.095} \\
\hline & $\mathrm{CA}$ & $\begin{array}{c}1274.4 \pm \\
1246.7\end{array}$ & & AG & $\begin{array}{c}1443.8 \pm \\
960.6\end{array}$ & & $\mathrm{CT}$ & $\begin{array}{c}892.4 \pm \\
478.8\end{array}$ & \\
\hline \multirow{2}{*}{ Days of ANC $<1 \times 10^{3} / \mathrm{mm}^{3}$} & $\mathrm{CC}$ & $\begin{array}{c}260.5 \pm \\
228.3\end{array}$ & \multirow[t]{2}{*}{0.540} & AA & $\begin{array}{c}262.4 \pm \\
223.6\end{array}$ & \multirow[t]{2}{*}{0.451} & $\mathrm{CC}$ & $\begin{array}{c}263.9 \pm \\
224.8\end{array}$ & \multirow[t]{2}{*}{0.564} \\
\hline & CA & $\begin{array}{c}290.1 \pm \\
218.3\end{array}$ & & AG & $\begin{array}{c}321.6 \pm \\
244.0\end{array}$ & & $\mathrm{CT}$ & $\begin{array}{c}285.9 \pm \\
231.2\end{array}$ & \\
\hline \multirow{2}{*}{ Days of ANC $<0.5 \times 10^{3} / \mathrm{mm}^{3}$} & $\mathrm{CC}$ & $\begin{array}{c}127.3 \pm \\
130.9\end{array}$ & \multirow[t]{2}{*}{0.317} & AA & $\begin{array}{c}131.6 \pm \\
128.2\end{array}$ & \multirow[t]{2}{*}{0.377} & $\mathrm{CC}$ & $\begin{array}{c}133.9 \pm \\
130.2\end{array}$ & \multirow[t]{2}{*}{0.527} \\
\hline & CA & $\begin{array}{c}163.2 \pm \\
134.6\end{array}$ & & AG & $\begin{array}{c}182.8 \pm \\
165.1\end{array}$ & & $\mathrm{CT}$ & $\begin{array}{c}148.3 \pm \\
142.7\end{array}$ & \\
\hline \multirow{2}{*}{ Days of febrile neutropenia } & $\mathrm{CC}$ & $6.00 \pm 5.56$ & \multirow{2}{*}{0.608} & AA & $5.9 \pm 5.3$ & \multirow{2}{*}{0.383} & $\mathrm{CC}$ & $5.7 \pm 5.1$ & \multirow{2}{*}{0.102} \\
\hline & $\mathrm{CA}$ & $6.52 \pm 4.70$ & & AG & $7.5 \pm 5.1$ & & $\mathrm{CT}$ & $7.5 \pm 6.0$ & \\
\hline \multirow{2}{*}{$\begin{array}{l}\text { 6-MP dose at second maintenance } \\
\text { period }\left(\mathrm{mg} / \mathrm{m}^{2}\right)\end{array}$} & $\mathrm{CC}$ & $50.5 \pm 7.45$ & \multirow{2}{*}{0.319} & AA & $51.4 \pm 19.1$ & \multirow{2}{*}{0.837} & $\mathrm{CC}$ & $53.0 \pm 19.5$ & \multirow{2}{*}{0.814} \\
\hline & CA & $54.6 \pm 19.0$ & & AG & $52.8 \pm 19.3$ & & CT & $45.6 \pm 15.9$ & \\
\hline \multirow{2}{*}{$\begin{array}{l}\text { 6-MP dose at sixth maintenance } \\
\text { period }\left(\mathrm{mg} / \mathrm{m}^{2}\right)\end{array}$} & $\mathrm{CC}$ & $48.3 \pm 16.7$ & \multirow{2}{*}{1.000} & AA & $47.9 \pm 17.1$ & \multirow{2}{*}{0.615} & $\mathrm{CC}$ & $51.0 \pm 15.6$ & \multirow{2}{*}{0.123} \\
\hline & $\mathrm{CA}$ & $48.8 \pm 16.4$ & & AG & $54.1 \pm 6.7$ & & $\mathrm{CT}$ & $38.1 \pm 16.3$ & \\
\hline 6-MP dose at final maintenance & $\mathrm{CC}$ & $45.6 \pm 15.5$ & 0912 & AA & $45.0 \pm 15.8$ & 0928 & $\mathrm{CC}$ & $47.7 \pm 13.8$ & 0007 \\
\hline treatment $\left(\mathrm{mg} / \mathrm{m}^{2}\right)$ & CA & $44.5 \pm 14.9$ & 0.912 & $\mathrm{AG}$ & $47.7 \pm 8.8$ & 0.928 & $\mathrm{CT}$ & $35.4 \pm 17.6$ & 0.007 \\
\hline 6-MP dose intensity ${ }^{\dagger}$ at second & $\mathrm{CC}$ & $68.1 \pm 25.6$ & 0235 & AA & $67.0 \pm 24.8$ & 0877 & $\mathrm{CC}$ & $72.7 \pm 24.3$ & 0127 \\
\hline maintenance period (\%) & CA & $75.2 \pm 21.9$ & 0.230 & AG & $70.4 \pm 25.8$ & $0.8 / 7$ & $\mathrm{CT}$ & $59.2 \pm 24.2$ & 0.127 \\
\hline 6-MP dose intensity ${ }^{+}$at sixth & $\mathrm{CC}$ & $65.5 \pm 23.1$ & 0780 & AA & $65.6 \pm 23.3$ & 0707 & $\mathrm{CC}$ & $70.6 \pm 20.1$ & 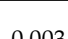 \\
\hline maintenance period $(\%)$ & $\mathrm{CA}$ & $68.2 \pm 21.0$ & 0.700 & AG & $72.1 \pm 9.0$ & נועל & $\mathrm{CT}$ & $49.4 \pm 23.6$ & 0.000 \\
\hline 6-MP dose intensity ${ }^{+}$at final & $\mathrm{CC}$ & $61.6 \pm 21.8$ & 0707 & AA & $61.5 \pm 21.7$ & 0866 & $\mathrm{CC}$ & $65.9 \pm 17.8$ & 0008 \\
\hline maintenance period (\%) & CA & $61.8 \pm 18.7$ & 0.192 & AG & $63.6 \pm 11.7$ & 0.866 & $\mathrm{CT}$ & $45.5 \pm 24.5$ & 0.008 \\
\hline
\end{tabular}


Table 2. Cont.

\begin{tabular}{|c|c|c|c|c|c|c|c|c|c|}
\hline \multirow[b]{2}{*}{ Charcteristics } & \multicolumn{3}{|c|}{ ITPA rs1127354 } & \multicolumn{3}{|c|}{ APEX rs2307486 } & \multicolumn{3}{|c|}{ NUDT15 rs116855232 } \\
\hline & Genotype & $\begin{array}{l}\text { CC }(n=62) \\
\text { CA }(n=21)\end{array}$ & $p$ & Genotype & $\begin{array}{c}\text { AA }(n=74) \\
\text { AG }(n=9)\end{array}$ & $p$ & Genotype & $\begin{array}{l}\text { CC }(n=67) \\
\text { CT }(n=16)\end{array}$ & $p^{*}$ \\
\hline \multirow{2}{*}{ Maximum AST } & $\mathrm{CC}$ & $\begin{array}{c}298.3 \pm \\
210.6 \\
\end{array}$ & \multirow{2}{*}{0.883} & AA & $\begin{array}{c}305.7 \pm \\
227.5 \\
\end{array}$ & 0.785 & $\mathrm{CC}$ & $\begin{array}{c}308.1 \pm \\
218.0\end{array}$ & \multirow{2}{*}{0.727} \\
\hline & CA & $\begin{array}{c}646.6 \pm \\
485.1 \\
\end{array}$ & & AG & $\begin{array}{c}286.8 \pm \\
154.6\end{array}$ & & $\mathrm{CT}$ & $\begin{array}{c}286.6 \pm \\
237.5\end{array}$ & \\
\hline \multirow{2}{*}{ Maximum ALT } & $\mathrm{CC}$ & $\begin{array}{c}646.7 \pm \\
485.1 \\
\end{array}$ & \multirow{2}{*}{0.974} & AA & $\begin{array}{c}655.0 \pm \\
474.0 \\
\end{array}$ & \multirow{2}{*}{0.255} & $\mathrm{CC}$ & $\begin{array}{c}658.0 \pm \\
478.4 \\
\end{array}$ & \multirow{2}{*}{0.427} \\
\hline & CA & $\begin{array}{c}606.9 \pm \\
383.6\end{array}$ & & AG & $\begin{array}{c}467.3 \pm \\
240.9\end{array}$ & & $\mathrm{CT}$ & $\begin{array}{c}549.1 \pm \\
369.1\end{array}$ & \\
\hline
\end{tabular}

$* p<0.05$ was considered statistically significant. ${ }^{+} 6$-MP dose intensity: the ratio of actual prescribed 6-MP dose by physician and the protocol dose. Abbreviations: ANC, absolute neutrophil count; 6-MP, 6-mercaptopurine; NUDT15, nucleoside diphosphate-linked moiety X-type motif 15; ITPA, inosine triphosphate pyrophosphatase; APEX1, apurinic/apyrimidinic endonuclease 1.

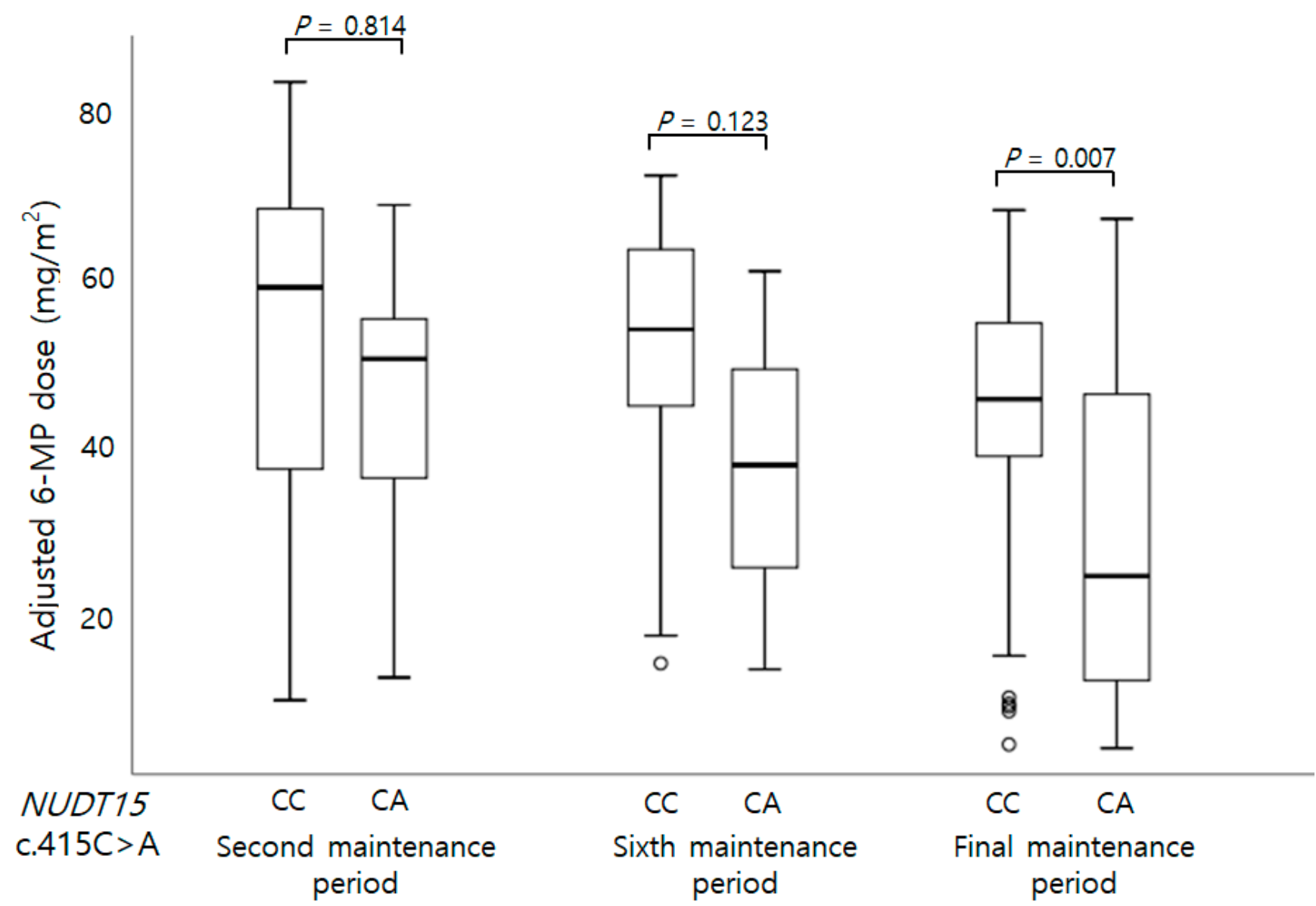

Figure 1. Genotype of NUDT15 c.415C >A and adjusted 6-MP dose at second, sixth, and final maintenance periods. The adjusted 6-MP dose at final maintenance period was significantly low in patients carrying CA heterozygote than those with wild CC genotype. 


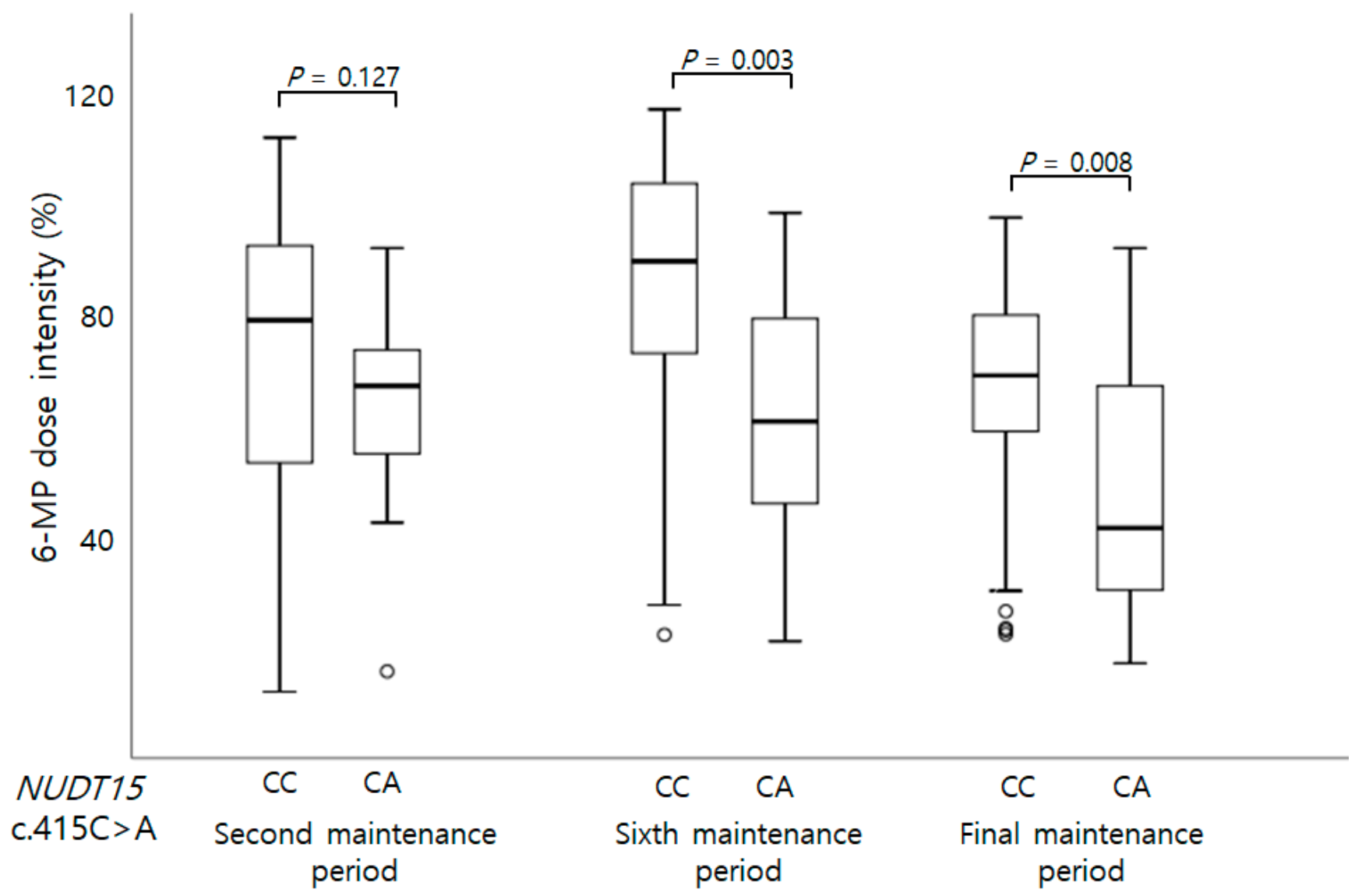

Figure 2. Genotype of NUDT15 c.415C>A and 6-MP dose intensity (\%) at second, sixth, and final maintenance periods. The 6-MP intensity was significantly low in patients carrying CA heterozygote than those with wild genotype at sixth and final maintenance therapy periods.

\section{Discussion}

In this study, the authors investigated the effects of major polymorphisms of four genes, NUDT15, ITPA, APEX1, TPMT on 6-MP-related toxicities or intolerance. Authors found that NUDT15 c.415C $>\mathrm{T}$ had a lowering effect on 6-MP dose during maintenance therapy in pediatric ALL patients.

As reported in previous studies, the TPMT and ITPA c.IVS2+21A $>\mathrm{C}$ variants were extremely low in our study population $[12,28]$. Thus, ITPA c.IVS2+21A $>C$ and TPMT variants were inappropriate for use as a pharmacogenetic marker for thiopurine therapy in Korean ALL patients. The frequencies of ITPA c. $94 \mathrm{C}>\mathrm{A}$ and APEX1 c.190A $>\mathrm{G}$ were $25.3 \%$ and $10.8 \%$, respectively. This is similar with previous studies reporting $21.9-27.0 \%$ [28,29], and $14.1 \%$ for Korean population [22].

The NUDT15 c.415C>T variant was reported to be a major predictive marker for thiopurine-related myelosuppression, particularly in Asian and Hispanic people. Yang et al. identified NUDT15 c.415C $>$ T as being strongly associated with thiopurine-induced early leukopenia in Crohn's disease [12]. Tanaka et al. found that leucopenia is more common in NUDT15 c.415C $>$ T carriers in pediatric ALL patient, and leucopenia results in a significant 6-MP dose reduction [30]. In our study, we collected information about neutropenia, such as the days with $<5 \times 10^{3}$ and $<1 \times 10^{3} / \mathrm{mm}^{3}$ neutropenia, days with febrile neutropenia, and we took an ANC on day 14 and 28 of maintenance therapy as early neutropenia index. But we found no significant relationship between genotypes and early neutropenia, neutropenic duration, and febrile neutropenia. However, the doses of 6-MP and dose intensity at the sixth, and final maintenance therapy sessions were significantly low in NUDT15 c.415C $>$ T carriers. The clinicians regulated the 6-MP doses according to the patients' neutrophil count, 
fever event, hepatotoxicity, or patient health status. Therefore, the adjustment of the 6-MP dose could be an indicator for 6-MP intolerance. Yi et al. reported a low 6-MP dose and longer duration of therapy interruption in NUDT15 c.415C>T carriers [31]. Moreover, Yang et al. found NUDT15 c.415C>T homozygote carriers were exquisitely sensitive to MP, with a significantly low average dose intensity of $8 \%$ in child ALL patients [13]. In addition to NUDT15 c.415C>T, other variants such as p.Arg139His, p.Val18Ile, p.Val18_Val19insGlyVal, p.Arg34Thr, p.Lys35-Glu, p.Gly17_Val18del, p.Met1Thr, and p.Gly47Arg have also been uncovered. Except for p.Val18_Val19insGlyVal (c.55_56insGAGTCG), other variants are present very infrequently, but these variants also showed the effect of a $74.4-100 \%$ loss of nucleotide diphosphatase activity resulting in excessive levels of thiopurine active metabolites and toxicity [16,32]. In particular, the p.G17_V18del variant protein showed extremely low thermostability and was completely void of catalytic activity, thus likely to confer a high risk of thiopurine intolerance [32]. To find out the mechanism of this NUDT15 variant, a few in vivo studies were conducted. In a recent study of the knock-in mouse model, the NUDT15-/- mice experienced severe leukopenia, rapid weight loss, early death, and more bone marrow hypocellularity on 6-MP therapy as compared to the wild type mice [33]. In another study, a clinically relevant dose of MP induced lethal cytopenia in NUDT15 c.415C > T harboring mice not only in the homozygote variant but also in the heterozygote variant. Even lower-dose MP during long-term administration caused stronger damage than wild type [34]. These in vivo studies support the preemptive NUDT15 genotype-guided thiopurine dosing to prevent toxicity.

Before NUDT15, a variant of ITPA was represented as a potential marker of 6-MP sensitivity, especially in populations with a low frequency of the TPMT variant. But the clinical relevance of ITPA genotyping in 6-MP toxicity prediction is still controversial [35-37]. In our study, although the frequency of ITPA c.94C $>$ A was sufficiently high, we could not discover a significant relationship with neutropenia or 6-MP dosing. A total of five patients carried both the ITPA c.94C >A and NUDT15 c.415C > T variants. We then compared those patients having only NUDT15 variant with those who had both the NUDT15 and ITPA variants to analyze their synergistic effects. Although those with both variations were likely to have the lower ANC on the 14th day, we could not find any statistically significant differences of neutropenia or 6-MP dose between either the NUDT15 carriers or both carriers (Supplementary Table S1). To analyze the synergistic effects of additional other variants, a study of a larger populations is needed.

APEX1 c.190A > G has relatively recently been proposed as a candidate gene, which has been revealed to have a strong relation with early onset MP-related neutropenia occurring within 28 days as well as a cumulative incidence of MP-related neutropenia [22]. Human $A P E X 1$ is the major enzyme in the DNA base excision repair pathway where its main role is to create a nick in the phosphodiester backbone [23]. The allele frequencies of the variant alleles in c. $190 \mathrm{~A}>\mathrm{G}$ were near $0 \%$ in Europeans, $0.08 \%$ in Africans, and 1.73\% in Americans, whereas they were $4.66 \%$ in East Asian individuals, according to the 1000 Genomes database [22]. In the previous study of McNeill et al., APEX1-deficient cells were shown to exhibit the greatest sensitivity to antimetabolites among various anticancer drugs, and consequently apoptotic cell death was profoundly increased, supporting a role for mutant APEX1 in thiopurine-induced neutropenia [23]. In our study, although the patient number is small, the frequency of variants was relatively high, $10.8 \%$, and all of them were heterozygote. Although a meaningful effect on 6-MP toxicities was not found in this study, a larger-scale study is needed for a new candidate gene.

The low incidence of the TPMT variant in Asian population has brought a discovery of new pharmacogenetic markers predicting 6-MP toxicities, such as NUDT15, ITPA, and $A P E X 1$. As new markers have been uncovered, identification of clinical significance and the synergic effect of those markers has been important. In this study, we could not find a distinct predictive role for these variations and their synergistic effect on myelosuppression such as neutropenia, but carriers with NUDT15 c.415C $>$ T showed lowered 6-MP dose meaning 6-MP intolerance. This limited result might be due to the relatively low numbers of 
patients or retrospective study design. The sample size of the study is small for assessment of multiple genetic variations and multiple outcomes measurements. Controlling for important covariates is difficult. Because the clinicians already had regulated the 6-MP dose according to the patients' health state including an ANC, the neutropenic effects of 6-MP might be obscured.

In future studies, a personalized 6-MP dosing plan will be applied in consideration of pharmacokinetics. It is also necessary to validate the effect of NUDT15, TPMT, APEX1, and ITPA genetic variations on 6-MP dosing of pediatric ALL through large-scale studies. These studies would help clarify new candidates and increase the number of patients who can benefit from the various pharmacogenetic markers.

Supplementary Materials: The following are available online at https://www.mdpi.com/2227-9 067/8/3/224/s1. Table S1: Comparison of parameters for 6-MP-related toxicities and intolerance between carriers with NUDT15 c.415C > T and those with both NUDT15 c.415C $>$ T and ITPA c.94C $>$ A.

Author Contributions: Conceptualization, J.M.L., Y.J.S. and J.-S.H.; methodology and investigation, J.M.L. and J.-S.H.; formal analysis, J.M.L., Y.J.S. and J.-S.H.; data curation J.M.L., D.-H.K., N.J. and Y.J.S.; writing—original draft preparation, J.M.L., Y.J.S., D.-H.K., N.J. and J.-S.H.; writing—review and editing, J.M.L., Y.J.S. and J.-S.H.; supervision, J.-S.H. All authors have read and agreed to the published version of the manuscript.

Funding: This work was supported by the research promoting grant from the Institute for Cancer Research Keimyung University Dongsan Medical Center in 2019.

Institutional Review Board Statement: The study was conducted according to the guidelines of the Declaration of Helsinki, and approved by the Institutional Review Board of Yeungnam University Hospital (YUMC 2019-12-007) and Keiymung University Dongsan Hospital (2019-11-074).

Informed Consent Statement: Informed consent was obtained from all subjects involved in the study.

Data Availability Statement: The data presented in this study are available on request from the corresponding author.

Acknowledgments: We thank K.S.P., K.S.L., T.Y.P. and S.H.W. for good assistance with sample collection, DNA extraction and sequencing analysis.

Conflicts of Interest: The authors declare no conflict of interest.

\section{References}

1. Kato, M.; Manabe, A. Treatment and biology of pediatric acute lymphoblastic leukemia. Pediatrics Int. Off. J. Jpn. Pediatr. Soc. 2018, 60, 4-12. [CrossRef] [PubMed]

2. Bhatia, S.; Landier, W.; Hageman, L.; Chen, Y.; Kim, H.; Sun, C.L.; Kornegay, N.; Evans, W.E.; Angiolillo, A.L.; Bostrom, B.; et al. Systemic Exposure to Thiopurines and Risk of Relapse in Children With Acute Lymphoblastic Leukemia: A Children's Oncology Group Study. JAMA Oncol. 2015, 1, 287-295. [CrossRef] [PubMed]

3. Wahlund, M.; Nilsson, A.; Kahlin, A.Z.; Broliden, K.; Myrberg, I.H.; Appell, M.L.; Berggren, A. The Role of TPMT, ITPA, and NUDT15 Variants during Mercaptopurine Treatment of Swedish Pediatric Patients with Acute Lymphoblastic Leukemia. J. Pediatr. 2020, 216, 150-157.e1. [CrossRef] [PubMed]

4. Su, Y.; Hon, Y.Y.; Chu, Y.; Van de Poll, M.E.; Relling, M.V. Assay of 6-mercaptopurine and its metabolites in patient plasma by high-performance liquid chromatography with diode-array detection. J. Chromatogr. B Biomed. Sci. Appl. 1999, 732, 459-468. [CrossRef]

5. Brem, R.; Karran, P. Oxidation-mediated DNA cross-linking contributes to the toxicity of 6-thioguanine in human cells. Cancer Res. 2012, 72, 4787-4795. [CrossRef] [PubMed]

6. Valerie, N.C.; Hagenkort, A.; Page, B.D.; Masuyer, G.; Rehling, D.; Carter, M.; Bevc, L.; Herr, P.; Homan, E.; Sheppard, N.G.; et al. NUDT15 Hydrolyzes 6-Thio-DeoxyGTP to Mediate the Anticancer Efficacy of 6-Thioguanine. Cancer Res. 2016, 76, 5501-5511. [CrossRef] [PubMed]

7. Evans, W.E.; Hon, Y.Y.; Bomgaars, L.; Coutre, S.; Holdsworth, M.; Janco, R.; Kalwinsky, D.; Keller, F.; Khatib, Z.; Margolin, J.; et al. Preponderance of thiopurine S-methyltransferase deficiency and heterozygosity among patients intolerant to mercaptopurine or azathioprine. J. Clin. Oncol. Off. J. Am. Soc. Clin. Oncol. 2001, 19, 2293-2301. [CrossRef] [PubMed]

8. Schmiegelow, K.; Forestier, E.; Kristinsson, J.; Söderhäll, S.; Vettenranta, K.; Weinshilboum, R.; Wesenberg, F. Thiopurine methyltransferase activity is related to the risk of relapse of childhood acute lymphoblastic leukemia: Results from the NOPHO ALL-92 study. Leukemia 2009, 23, 557-564. [CrossRef] 
9. Relling, M.V.; Altman, R.B.; Goetz, M.P.; Evans, W.E. Clinical implementation of pharmacogenomics: Overcoming genetic exceptionalism. Lancet Oncol. 2010, 11, 507-509. [CrossRef]

10. Chang, J.G.; Lee, L.S.; Chen, C.M.; Shih, M.C.; Wu, M.C.; Tsai, F.J.; Liang, D.C. Molecular analysis of thiopurine S-methyltransferase alleles in South-east Asian populations. Pharmacogenetics 2002, 12, 191-195. [CrossRef]

11. Moradveisi, B.; Muwakkit, S.; Zamani, F.; Ghaderi, E.; Mohammadi, E.; Zgheib, N.K. ITPA, TPMT, and NUDT15 Genetic Polymorphisms Predict 6-Mercaptopurine Toxicity in Middle Eastern Children With Acute Lymphoblastic Leukemia. Front. Pharmacol. 2019, 10, 916. [CrossRef]

12. Yang, S.K.; Hong, M.; Baek, J.; Choi, H.; Zhao, W.; Jung, Y.; Haritunians, T.; Ye, B.D.; Kim, K.J.; Park, S.H.; et al. A common missense variant in NUDT15 confers susceptibility to thiopurine-induced leukopenia. Nat. Genet. 2014, 46, 1017-1020. [CrossRef] [PubMed]

13. Yang, J.J.; Landier, W.; Yang, W.; Liu, C.; Hageman, L.; Cheng, C.; Pei, D.; Chen, Y.; Crews, K.R.; Kornegay, N.; et al. Inherited NUDT15 variant is a genetic determinant of mercaptopurine intolerance in children with acute lymphoblastic leukemia. J. Clin. Oncol. Off. J. Am. Soc. Clin. Oncol. 2015, 33, 1235-1242. [CrossRef]

14. Kakuta, Y.; Naito, T.; Onodera, M.; Kuroha, M.; Kimura, T.; Shiga, H.; Endo, K.; Negoro, K.; Kinouchi, Y.; Shimosegawa, T. NUDT15 R139C causes thiopurine-induced early severe hair loss and leukopenia in Japanese patients with IBD. Pharm. J. 2016, 16, 280-285. [CrossRef]

15. Kakuta, Y.; Kawai, Y.; Okamoto, D.; Takagawa, T.; Ikeya, K.; Sakuraba, H.; Nishida, A.; Nakagawa, S.; Miura, M.; Toyonaga, T.; et al. NUDT15 codon 139 is the best pharmacogenetic marker for predicting thiopurine-induced severe adverse events in Japanese patients with inflammatory bowel disease: A multicenter study. J. Gastroenterol. 2018, 53, 1065-1078. [CrossRef]

16. Moriyama, T.; Nishii, R.; Perez-Andreu, V.; Yang, W.; Klussmann, F.A.; Zhao, X.; Lin, T.N.; Hoshitsuki, K.; Nersting, J.; Kihira, K.; et al. NUDT15 polymorphisms alter thiopurine metabolism and hematopoietic toxicity. Nat. Genet. 2016, 48, 367-373. [CrossRef]

17. Asada, A.; Nishida, A.; Shioya, M.; Imaeda, H.; Inatomi, O.; Bamba, S.; Kito, K.; Sugimoto, M.; Andoh, A. NUDT15 R139Crelated thiopurine leukocytopenia is mediated by 6-thioguanine nucleotide-independent mechanism in Japanese patients with inflammatory bowel disease. J. Gastroenterol. 2016, 51, 22-29. [CrossRef]

18. Kim, H.T.; Choi, R.; Won, H.H.; Choe, Y.H.; Kang, B.; Lee, K.; Koo, H.H.; Yoo, K.H.; Kim, Y.H.; Lee, S.Y. NUDT15 genotype distributions in the Korean population. Pharm. Genom. 2017, 27, 197-200. [CrossRef]

19. Stocco, G.; Cheok, M.H.; Crews, K.R.; Dervieux, T.; French, D.; Pei, D.; Yang, W.; Cheng, C.; Pui, C.H.; Relling, M.V.; et al. Genetic polymorphism of inosine triphosphate pyrophosphatase is a determinant of mercaptopurine metabolism and toxicity during treatment for acute lymphoblastic leukemia. Clin. Pharmacol. Ther. 2009, 85, 164-172. [CrossRef] [PubMed]

20. Sumi, S.; Marinaki, A.M.; Arenas, M.; Fairbanks, L.; Shobowale-Bakre, M.; Rees, D.C.; Thein, S.L.; Ansari, A.; Sanderson, J.; De Abreu, R.A.; et al. Genetic basis of inosine triphosphate pyrophosphohydrolase deficiency. Hum. Genet. 2002, 111, 360-367. [CrossRef] [PubMed]

21. Marsh, S.; King, C.R.; Ahluwalia, R.; McLeod, H.L. Distribution of ITPA P32T alleles in multiple world populations. J. Hum. Genet. 2004, 49, 579-581. [CrossRef] [PubMed]

22. Kim, H.; Seo, H.; Park, Y.; Min, B.J.; Seo, M.E.; Park, K.D.; Shin, H.Y.; Kim, J.H.; Kang, H.J. APEX1 Polymorphism and Mercaptopurine-Related Early Onset Neutropenia in Pediatric Acute Lymphoblastic Leukemia. Cancer Res. Treat. Off. J. Korean Cancer Assoc. 2018, 50, 823-834. [CrossRef]

23. McNeill, D.R.; Lam, W.; DeWeese, T.L.; Cheng, Y.C.; Wilson, D.M., 3rd. Impairment of APE1 function enhances cellular sensitivity to clinically relevant alkylators and antimetabolites. Mol. Cancer Res. MCR 2009, 7, 897-906. [CrossRef]

24. Schultz, K.R.; Pullen, D.J.; Sather, H.N.; Shuster, J.J.; Devidas, M.; Borowitz, M.J.; Carroll, A.J.; Heerema, N.A.; Rubnitz, J.E.; Loh, M.L.; et al. Risk- and response-based classification of childhood B-precursor acute lymphoblastic leukemia: A combined analysis of prognostic markers from the Pediatric Oncology Group (POG) and Children's Cancer Group (CCG). Blood 2007, 109, 926-935. [CrossRef]

25. Smith, M.; Arthur, D.; Camitta, B.; Carroll, A.J.; Crist, W.; Gaynon, P.; Gelber, R.; Heerema, N.; Korn, E.L.; Link, M.; et al. Uniform approach to risk classification and treatment assignment for children with acute lymphoblastic leukemia. J. Clin. Oncol. Off. J. Am. Soc. Clin. Oncol. 1996, 14, 18-24. [CrossRef]

26. Schmiegelow, K.; Nersting, J.; Nielsen, S.N.; Heyman, M.; Wesenberg, F.; Kristinsson, J.; Vettenranta, K.; Schrøeder, H.; Weinshilboum, R.; Jensen, K.L.; et al. Maintenance therapy of childhood acute lymphoblastic leukemia revisited-Should drug doses be adjusted by white blood cell, neutrophil, or lymphocyte counts? Pediatr. Blood Cancer 2016, 63, 2104-2111. [CrossRef] [PubMed]

27. Schmiegelow, K.; Nielsen, S.N.; Frandsen, T.L.; Nersting, J. Mercaptopurine/Methotrexate maintenance therapy of childhood acute lymphoblastic leukemia: Clinical facts and fiction. J. Pediatr. Hematol. Oncol. 2014, 36, 503-517. [CrossRef]

28. Jung, Y.S.; Cheon, J.H.; Park, J.J.; Moon, C.M.; Kim, E.S.; Lee, J.H.; Kim, S.W.; Kim, J.H.; Hong, S.P.; Kim, T.I.; et al. Correlation of genotypes for thiopurine methyltransferase and inosine triphosphate pyrophosphatase with long-term clinical outcomes in Korean patients with inflammatory bowel diseases during treatment with thiopurine drugs. J. Hum. Genet. 2010, 55, 121-123. [CrossRef] [PubMed]

29. Cheon, J.H.; Kim, J.H.; Kim, B.Y.; Kim, S.W.; Hong, S.Y.; Eun, C.S.; Hong, S.S.; Byeon, J.S.; Kim, T.I.; Han, D.S.; et al. Allele frequency of thiopurine methyltransferase and inosine triphosphate pyrophosphatase gene polymorphisms in Korean patients with inflammatory bowel diseases. Hepato-Gastroenterology 2009, 56, 421-423. 
30. Tanaka, Y.; Kato, M.; Hasegawa, D.; Urayama, K.Y.; Nakadate, H.; Kondoh, K.; Nakamura, K.; Koh, K.; Komiyama, T.; Manabe, A. Susceptibility to 6-MP toxicity conferred by a NUDT15 variant in Japanese children with acute lymphoblastic leukaemia. Br. J. Haematol. 2015, 171, 109-115. [CrossRef]

31. Yi, E.S.; Choi, Y.B.; Choi, R.; Lee, N.H.; Lee, J.W.; Yoo, K.H.; Sung, K.W.; Lee, S.Y.; Koo, H.H. NUDT15 Variants Cause Hematopoietic Toxicity with Low 6-TGN Levels in Children with Acute Lymphoblastic Leukemia. Cancer Res. Treat. Off. J. Korean Cancer Assoc. 2018, 50, 872-882. [CrossRef] [PubMed]

32. Moriyama, T.; Yang, Y.L.; Nishii, R.; Ariffin, H.; Liu, C.; Lin, T.N.; Yang, W.; Lin, D.T.; Yu, C.H.; Kham, S.; et al. Novel variants in NUDT15 and thiopurine intolerance in children with acute lymphoblastic leukemia from diverse ancestry. Blood 2017, 130, 1209-1212. [CrossRef] [PubMed]

33. Nishii, R.; Moriyama, T.; Janke, L.J.; Yang, W.; Suiter, C.C.; Lin, T.N.; Li, L.; Kihira, K.; Toyoda, H.; Hofmann, U.; et al. Preclinical evaluation of NUDT15-guided thiopurine therapy and its effects on toxicity and antileukemic efficacy. Blood 2018, 131, 2466-2474. [CrossRef]

34. Tatsumi, G.; Kawahara, M.; Imai, T.; Nishishita-Asai, A.; Nishida, A.; Inatomi, O.; Yokoyama, A.; Kakuta, Y.; Kito, K.; Andoh, A. Thiopurine-mediated impairment of hematopoietic stem and leukemia cells in NUDT15(R138C) knock-in mice. Leukemia 2020, 34, 882-894. [CrossRef]

35. Simone, P.D.; Pavlov, Y.I.; Borgstahl, G.E. ITPA (inosine triphosphate pyrophosphatase): From surveillance of nucleotide pools to human disease and pharmacogenetics. Mutat. Res. 2013, 753, 131-146. [CrossRef] [PubMed]

36. Zhou, H.; Li, L.; Yang, P.; Yang, L.; Zheng, J.E.; Zhou, Y.; Han, Y. Optimal predictor for 6-mercaptopurine intolerance in Chinese children with acute lymphoblastic leukemia: NUDT15, TPMT, or ITPA genetic variants? BMC Cancer 2018, 18, 516. [CrossRef] [PubMed]

37. Milosevic, G.; Kotur, N.; Krstovski, N.; Lazic, J.; Zukic, B.; Stankovic, B.; Janic, D.; Katsila, T.; Patrinos, G.P.; Pavlovic, S.; et al. Variants in TPMT, ITPA, ABCC4 and ABCB1 Genes As Predictors of 6-mercaptopurine Induced Toxicity in Children with Acute Lymphoblastic Leukemia. J. Med. Biochem. 2018, 37, 320-327. [CrossRef] [PubMed] 